\title{
The Network Strategy of Integrated Service Centers for Women and Children Empowerment Actors in Strengthening Institutions in the Socio-Cultural Environment of Palembang City, South Sumatera
}

\section{Nengyanti ${ }^{1}$, Yoyok Hendarso ${ }^{2}$, and Dwi Mirani ${ }^{3}$ \\ ${ }^{1}$ Population Graduate Program Lecturer, University of Sriwijaya, Palembang, Indonesia \\ ${ }^{2}$ Sociology Graduate Program Lecturer, University of Sriwijaya, Palembang, Indonesia \\ ${ }^{3}$ Public Administration Lecturer, University of Sriwijaya, Palembang, Indonesia}

\section{Abstract}

The purpose of this study is to identify and analyze the strategies used to strengthen the network of the Integrated Service Center for Women and Children Empowerment Palembang (P2TP2A) actors. Previous studies on the actor networking model showed that the implementation of the P2TP2A actor network did not occur in accordance with the government mandate. This shows the need to identify suitable strategies so that the functions and objectives of the P2TP2A actor network can be achieved optimally in accordance with government policies. The study design used in this study is exploratory descriptive. Primary and secondary data sources are used. Data collection was done via group discussion forums (integrated discussion) and cross-checked through in-depth interviews. The informants in the study are the actors involved as administrators of the P2TP2A Palembang. The results of the study on the analysis of actor network strategies P2TP2A is to indwell P2TP2A by increasing sensitivity and gender awareness (focal point) of every actor involved in the P2TP2A team so that the network actors of P2TP2A can be strengthened. The researcher recommends the modification of the mayor regulation on the formation of the P2TP2A team policy, especially regarding the mechanism and working procedures of planning and compilation of activities, implementation and evaluation that can be considered for planning activities or actions for the coming year.

Keywords: P2TP2A, actor networking, strategy
Selection and Peer-review unde the responsibility of the IC-HEDS 2019 Conference Committee.

\section{G OPEN ACCESS}

\section{Introduction}

The violence against women and children issues are often regarded as a personal matter of a person thus making government's innovative efforts to deal with these issues stagnated. Public policies in the form of protection for women and children victims of violence through Integrated Services Unit are difficult to implement. Violence against 
women and children is like an "iceberg" since there are still many cases left unreported. Previous study on the actor networking model at the Palembang Integrated Women's and Children's Empowerment Service Center (P2TP2A), showed that the implementation of the P2TP2A actor network was not in accordance with the Ministry of PP-PA mandate and implemented regional regulations [1].

A total of 38 actors consisting 30 human actors, 8 non-human actors, and 2 actants were involved in implementing P2TP2A implementation. Unfortunately, only a few actors actually carry out their role forming networks to achieve policies that empower women and protect children. Human actors and non-human actors have not worked synergistically in forming an ideal network as the path written in the P2TP2A Regional Regulation. The actor network is not yet integrated and sustainable at each stage (partial) as a form of main duty and function of the Palembang City PP-PA Office. Based on the results of previous studies, the Integrated Services Unit has not run according to the provisions, even though it has been established for quite a long time. This shows the need to identify the P2TP2A actor network strategy that suitable in the field so that the functions and objectives of the policy can be achieved optimally. Based on that, the aims of this study is to identify and analyze the strategies in strengthening the network of the Integrated Service Center for Women and Children Empowerment Palembang (P2TP2A) actors. In addition, this study is expected to be a mediator in forming a strategy for implementing a better P2TP2A actor network model.

\section{Methods}

The research design used in this research is descriptive exploratory, descriptive research carried out by analyzing and presenting data systemically, so that it can be more easily understood and concluded. While explorative research aims to find something new in the form of a grouping of symptoms or certain facts. Data sources used are primary and secondary data. Data collection is done by observation, interviews, documentation, group discussion forums, and literature studies. The informants in this study were the actors involved as administrators of the P2TP2A Palembang. The validity test of the data used is triangulation from Cresswell [2] by checking the data to the same source with different techniques. Then, the data is analyzed by managing and interpreting the data, reading the entire data, analyzing in more detail by coding the data, describing the coding and interpreting the data. 


\section{Results}

\subsection{General Description of Violence against Women and Children in Palembang City}

According to the Head of Women's Empowerment, Office of Women's and Children's Empowerment, the majority of violences against women and children in Palembang are in the form of sexual violences shown in table 1, 2,3 and Figure 2. In general, women tend not to report economic, psychological, or even physical violence they experienced. From the data that has been unraveled based on various criteria, the P2TP2A team must have been able to work synergically in planning and organizing actions needed even though those proposals will still need to be submitted to the relevant agencies or institutions. Planning and compiling preventive and curative actions to protect and empower women and children after receiving or becoming victims of violence is important and must be carried out by all P2TP2A members so that women and children victims of violence can recover and have productive activities.

TABLE 1: Types of Violence against Women and Children in South Sumatra Province

Types of Violence
Rape and Sexual Harassment
Domestic Violence
Dating Violence
Trafiking
Other Violence
Total

\begin{tabular}{|c|c|}
\hline \multicolumn{2}{|c|}{2017} \\
\hline 63 & $33,6 \%$ \\
\hline 57 & $30,5 \%$ \\
\hline 39 & $20,9 \%$ \\
\hline 1 & $0,5 \%$ \\
\hline 27 & $14,5 \%$ \\
\hline 187 & $100 \%$ \\
\hline
\end{tabular}

\begin{tabular}{|c|c|}
\hline \multicolumn{2}{|c|}{2018} \\
\hline 79 & $59,3 \%$ \\
\hline 32 & $24,3 \%$ \\
\hline 14 & $10,5 \%$ \\
\hline 1 & $0,7 \%$ \\
\hline 7 & $5,2 \%$ \\
\hline 133 & $100 \%$ \\
\hline
\end{tabular}

Source: Woman Crisis Center Palembang, 2019

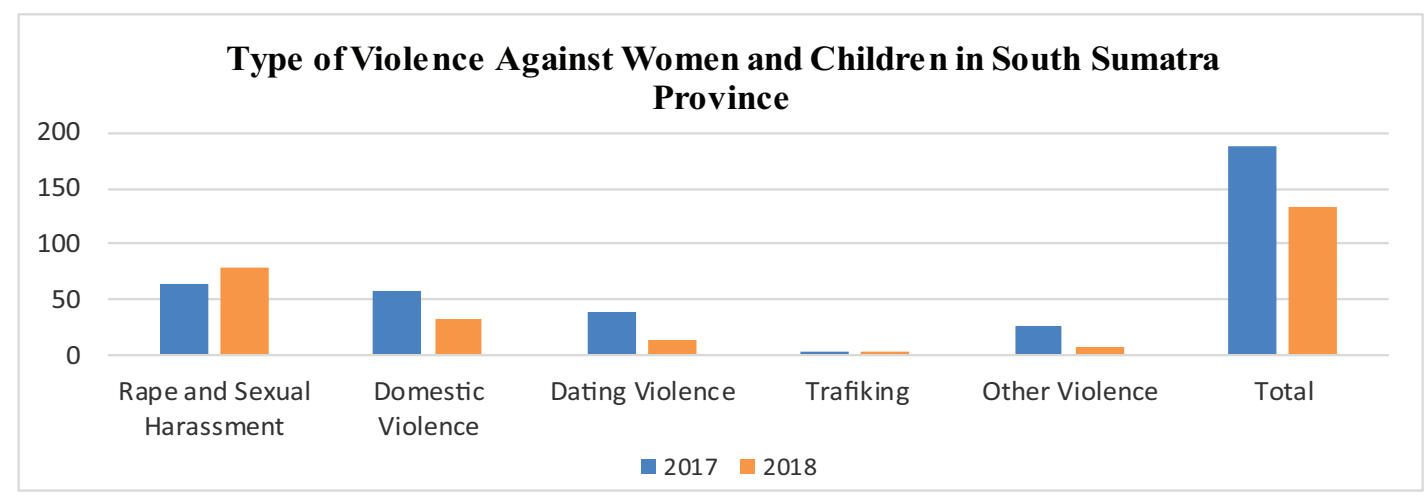

Figure 1: Number of Violence Cases per Type of Violence. Source: Woman Crisis Center Palembang, 2019 
TABLE 2: Age of Victims and Perpetrators

\begin{tabular}{|l|c|c|c|c|}
\hline Age & \multicolumn{3}{|c|}{2017} & \multicolumn{2}{c}{2018} \\
\hline$<5$ & Victim & Perpetrator & Victim & Perpetrator \\
\hline $6-12$ & 6 & 1 & 2 & 0 \\
\hline $13-18$ & 32 & 21 & 9 & 3 \\
\hline $19-24$ & 45 & 25 & 34 & 9 \\
\hline $25-40$ & 35 & 37 & 27 & 29 \\
\hline$>40$ & 57 & 69 & 44 & 52 \\
\hline Unknown & 12 & 16 & 17 & 11 \\
\hline T O T A L & - & 23 & & 22 \\
\hline
\end{tabular}

Source: Woman Crisis Center Palembang, 2019

TABLE 3: Education Level of Victims and Perpetrators

Level of Education
$<5$ th
Primary School
Junior High School
Senior High School
College (undergraduate)
Other (graduate/postgraduate)
Unknown
T O T A L

\begin{tabular}{|c|c|}
\hline \multicolumn{2}{|c|}{2017} \\
\hline Victim & Perpetrator \\
\hline 6 & 9 \\
\hline 32 & 28 \\
\hline 45 & 34 \\
\hline 35 & 59 \\
\hline 57 & 14 \\
\hline 12 & 7 \\
\hline- & 41 \\
\hline 187 & 192 \\
\hline
\end{tabular}

\begin{tabular}{|c|c|}
\hline \multicolumn{2}{|c|}{2018} \\
\hline Victim & Perpetrator \\
\hline 2 & 1 \\
\hline 14 & 7 \\
\hline 37 & 21 \\
\hline 66 & 54 \\
\hline 12 & 18 \\
\hline 2 & 4 \\
\hline- & 31 \\
\hline 133 & 136 \\
\hline
\end{tabular}

Source: Woman Crisis Center Palembang, 2019

\section{Discussion}

\subsection{The Study Results related to the P2TP2A Actor Network Strat- egy in Palembang}

The strategy of strengthening the P2TP2A institution has been carried out by the Palembang City Government by issuing the Decree of the Mayor of Palembang No. 542 / KPTS / XI / 2015 concerning changes to the Decree of Palembang Mayor No. 491 of 2013 concerning Management of the Integrated Service Center for the Empowerment of Women and Children (P2TP2A) Palembang City during 2013-2018. The policies made only regulates the institutional organization structure and duties of each division formed. The collaborative framework between institutions, both Family Welfare Empowerment government agencies, NGOs, and security forces has not been regulated so the implementation seems to be just "waiting" and not holistic. This is consistent with the results of an interview with the Head of the Women's Empowerment Office of the Women's 
Empowerment, Child Protection, and Community Empowerment Service in Palembang, "The coordination and collaboration of work to optimize the P2TP2A of Palembang City cannot yet be done. The sectoral ego and the obligation to follow superiors' policies remain a barrier. If the supervisor does not care about the issue, then the P2TP2A Team's policy implementation will not be maximal. Only reported cases will be followed up on. If P2TP2A does not have funds, usually a request will be made to the Women Crisis Center (WCC) to assist the victim, including accompanying victims making visum et repertum report".

According to the Head of the Women's Empowerment Office of the PPPAPM Office in Palembang, basically synergistic planning to determine the action needed for the next year based on cases and obstacles in the previous year could have been done, but this planning still depends on the decision of the superiors. The plan will not be carried out if not in accordance with superiors' desires. Employees must obey the policies made by superiors since their careers depend on their superiors. The Mayor of Palembang City issued the Mayor's Regulation No. 67 of 2017 (on December 22, 2017) concerning the Formation of the Regional Technical Implementation Unit (UPTD) of the Palembang, PPPAPM Service which makes the P2TP2A have no valid position. The UPTD works under the direction of the office secretary and division's head. UPTD acts as echelon III in the organizational structure. The UPTD is carrying out part of the operational tasks of the PPPAPM Service [3].

This UPTD is formed just to warranty the effort to protecting and empowering women and children will receive a budget allocation and have a team that will manage the budget, as regional apparatus organization. But unfortunately, based on interviews with the head of the UPTD, the organizational structure of the UPTD (including the team that manages the budget) has not been formed until now. There is no clear explanation regarding the operational implementation of the UPTD, both the number and competency of officers required, halfway houses, and operational vehicles. The Provincial Social Service has indeed offered one of the buildings that can be used, but unfortunately the operational costs of officers and victims of violence must be borne by the UPTD while the UPTD has not received a budget allocation. The head of the UPTD acknowledged that he did not yet have much knowledge about gender and the empowerment of women and children based on gender analysis. Both the head of the women's empowerment office and the head of the UPTD have not yet fully understood gender-responsive planning, implementation, and evaluation of development programs (Regional Revenue and Expenditure Budget). The pattern of activities is still considered 
the same as the standard activities in accordance with the general pattern of activities that have been adopted.

According to the WCC Director, the formation of the UPTD made the Mayor Regulation on the P2TP2A Team no longer valid, even though the formation of the P2TP2A Team itself was aimed at providing "special" empowerment and protection of violence in the form of gender-based protection which most of the protection was not gender based. If it the UPTD formation policy is examined thoroughly, the formation of UPTD which human resources are civil servants with unclear gender knowledge can cause assistance and advocacy functions of victims of violence against women and children not to be achieved optimally. Deep sensitivity and gender awareness are needed by every actor involved in the implementation of gender-based protection and empowerment policies. It is suspected that most State Civil Apparatus do not possess the sensitivity and gender awareness needed to be gender-based protection and empowerment policy actor.

The UPTD work mechanism has not yet been created based on problems analysis and the policy environment. This can lead to a problem since the P2TP2A team whose human resources have qualified knowledge with clear job desk for each division are still unable to work synergistically and collaboratively. In addition, most existing civil servants do not have a work culture that plans activities for the coming year in accordance with the implementation and evaluation of activities or actions which have been done or/and still ongoing. The division of tasks and supervision over the allocation of funds and the budget process that should be returned to their respective agencies and institutions based on jointly designed activities also has not been entrenched among UPTD members.

The leveling ability of the UPTD as the leading sector to accommodate P2TP2A as a cross-sector team and institution that has components with different positions (WCC (NGO) director, Women Studies Center (PSW) chairperson (University), and head division of Women and Children Protection at Regional Police is also questionable. The following is an overview of the draft research results related to strategies in strengthening the network of actors in the Integrated Service Center for Women and Children Empowerment (P2TP2A) City of Palembang related with increasing awareness of violence against women and children (gender) or raising awareness to the all public servants who get involved at the UPTD. Based on the results of the FGD and interviews, a strategy scheme is produced as presented in Figure 2.

Based on the above scheme, the strategy can be developed through 3 layers of management namely, top, middle, and low management. In top management, strategies can be developed through the participation of the mayor by addressing the issue 


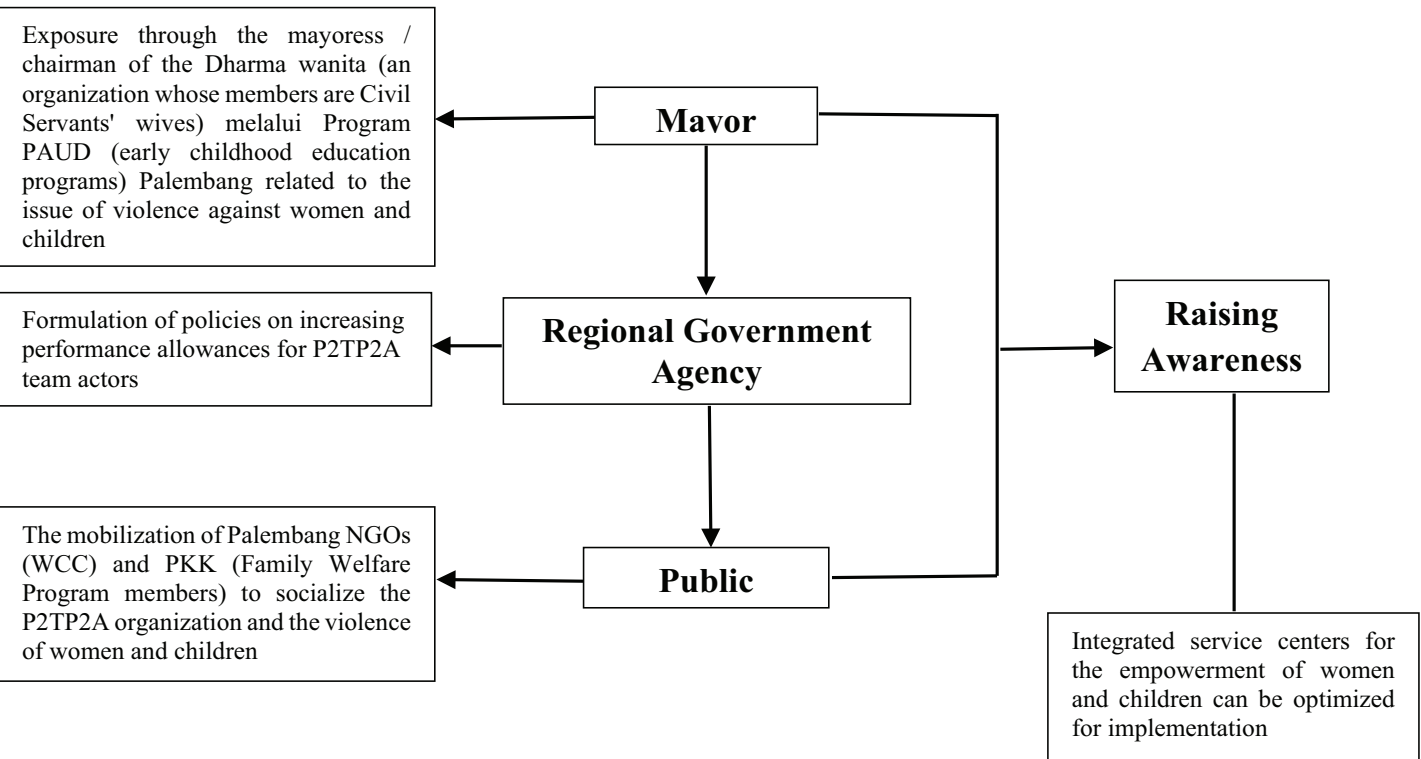

Figure 2: Strategic Scheme of Increasing Gender Sensitiveness/Awareness for Strengthening the Center for Integrated Service Centers for the Empowerment of Women and Children

of violence against women and children in Palembang. In the middle management, institutional strengthening strategies can be developed by increasing the performance allowances of civil servants involved in P2TP2A. Strengthening strategies for low management can be developed by mobilizing Non-Governmental Organizations (NGOs) and PKK groups to increase awareness of violence against women and children. This makes the researcher recommend that the P2TP2A team must stay up to strengthened institutionally by modifying the mayor regulations on the formation of the P2TP2A team policy, especially regarding the mechanism and working procedures of planning and compilation of activities, implementation and evaluation that can be considered for planning activities or actions for the coming year, not by forming UPTD. The mayor regulations modification recommended by researchers is expected to be the central point of the policy. In addition P2TP2A team actors must also have a focal point in the form of high sensitivity and gender awareness. Sensitivity and gender awareness are expected to be one of the requirements to become P2TP2A team actors, especially those who occupy important positions in P2TP2A. Training on sensitivity and gender awareness is needed by state civil apparatus so that they can become femocrats who are bureaucrats with high gender awareness and try to change unfair and unequal conditions into equal conditions. 


\section{Conclusion}

The results of the study on the analysis of actor network strategies at the Integrated Service Center for Empowering Women and Children (P2TP2A) is to increase sensitivity and gender awareness (focal point) by considering three layers management of organization namely top, middle, and bottom management as a strategy to strengthen institutions temporarily. In top management, the strategy can be developed through the participation of the mayor by giving a presentation related to the issue of violence against women and children in Palembang. In the middle management, institutional strengthening strategies can be developed by increasing the performance allowances of civil servants involved in P2TP2A. Then, in lower management, strategies can be developed through mobilizing NGOs (Non-Governmental Organizations) and PKK groups to raise violence against women and children awareness. The researcher recommends the modification of the mayor regulation regarding the formation of the P2TP2A team policy so that it not only discusses the people involved in P2TP2A but also discusses the work mechanism and procedures for planning and compiling activities, implementation and evaluation that can be considered for planning activities or actions for the coming year. The mayor regulation modification recommended by researchers is expected to be the central point of the policy.

\section{Funding}

This study was supported by Competitiveness Growth Research Program of The NonTax Revenue Funds 2019 of Sriwijaya University under Grant no [0149.150/SB3.LP2.PT/ 2019].

\section{Acknowledgement}

The authors would like to thank their colleague for their contribution and support to the research. They are also thankful to all the reviewers who gave their valuable inputs to the manuscript and helped in completing the paper.

\section{References}

[1] Nengyanti, D. (2018). Model Jejaring Aktor Pusat Pelayanan Terpadu Pemberdayaan Perempua dan Anak (P2TP2A) dalam Lingkungan Sosial Kota Palembang Provinsi 
Sumatera Selatan. In Proceedings of The Second International on Social Transformation Community and Sustainable Development. Unair: Magelang.

[2] Creswell, J. W. (2010). Research Design: Pendekatan Kualitatif, Kuantitatif dan Mixed. Yogyakarta: Pustaka Pelajar.

[3] Saputro, B. (2016). Analisis Jaringan Aktor dalam Implementasi Peraturan Daerah Kota Magelang Nomor 10 Tahun 2012 tentang Pengarusutamaan Gender. Palembang: Universitas Sriwijaya.

[4] Fadilah, U. (2012). Kinerja Pusat Pelayanan Terpadu Pemberdayaan Perempuan dan Anak (P2TP2A) dalam Penanganan Kasus Kekerasan Seksual Terhadap Anak di Provinsi Banten. Serang: Universitas Sultan Ageng Tirtayasa.

[5] Haloho, S. (2013). Efektivitas Kinerja Pusat Pelayanan Terpadu Pemberdayaan Perempuan dan Anak (P2TP2A) Provinsi Riau Tahun 2013 Dalam Menangani Kasus Kekerasan Dalam Rumah Tangga (KDRT). Journal Universitas Riau, vol 2, issue 1.

[6] Dwidjowojoto, R. N. (2006), Kebijakan Publik Untuk Negara-negara Berkembang. Jakarta: Elex Media Komputindo.

[7] Dye, T. R. (2011). Understanding Public Policy (14 ${ }^{\text {th }}$ ed.). Pearson Education, Inc.

[8] Edward III, G. C. (1990). Implementing Public Policy. Washington DC: Congressional Quartely Press.

[9] Grindle, M. (2013). Politics and Policy Implementation in the Third World. New York: Princenton University Press.

[10] Grand, M., Robert. (1999). Analisis Strategi Kontemporer. Jakarta: Erlangga.

[11] Ripley, R. B. (1985). Policy Analysis in Polical Science. Cicago: Nelson-Hall, Inc, p. 167.

[12] Solihin, I. (2012). Manajemen Strategik. Bandung: Erlangga

[13] Partowidagdo, W. (1999). Memahami Analisis Kebijakan. Bandung: Program Studi Pembangunan Program Pascasarjana ITB. 